\title{
Rothamsted carbon model reveals technical options to maintain soil organic carbon under semi-arid climate
}

\author{
Satoshi Nakamura Keiichi Hayashi • Hide Omae • \\ Dougbedji Fatondji • Ramadjita Tabo • Hitoshi Shinjo • \\ Addam Kiari Saidou • Satoshi Tobita
}

Accepted: 10 May 2012 / Published online: 8 June 2012

(C) INRA and Springer-Verlag, France 2012

\begin{abstract}
Soil organic matter in the Sahel is severely reduced by continuous cultivation. Reductions of soil organic matter decrease in turn soil productivity. Nonetheless, reports show that organic matter application in the Sahel improves crop yield. However, long-term effects of organic matter application on soil fertility have not been fully studied. In particular, it is essential to get information on organic matter decomposition and annual carbon requirement. Model simulation is suitable for evaluating long-term sustainability. The Rothamsted carbon model is convenient and has been recently validated for use in Sahelian conditions. Here, we studied the annual carbon requirement for sustainable soil organic carbon management in the Sahelian zone using datasets of short-term trials conducted in the Sahel. We
\end{abstract}

S. Nakamura $(\bowtie) \cdot K$. Hayashi $\cdot$ H. Omae $\cdot$ S. Tobita Crop, Livestock \& Environment Division, Japan International Research Center for Agricultural Sciences (JIRCAS), Tsukuba, Ibaraki 305-8686, Japan

e-mail: nsatoshi@affrc.go.jp

D. Fatondji

West \& Central Africa (ICRISAT-WCA), International Crops Research Center for the Semi-Arid Tropics, BP 12404, Niamey, Niger

R. Tabo

Forum for Agricultural Research in Africa (FARA), No. 12 Anmeda Street, Roman Ridge, Cantonments, PMB CT 173, Accra, Ghana

\section{H. Shinjo}

Graduate School of Agriculture, Kyoto University, Kyoto 606-8502, Japan

\section{A. K. Saidou}

Institut National de Recherches Agronomiques du Niger (INRAN), BP 429, Niamey, Niger estimated the long-term effect of various agricultural managements on soil organic carbon dynamics as one of the soil fertility indices. The 10-year soil organic carbon value changes were predicted by the Rothamsted carbon model for 59 treatments. Results show that, contrary to previous short-term experiments that indicated crop yield enhancement, these technical options also cause a decline in soil organic carbon if enough organic resource is not applied. Soil productivity should therefore decrease. The annual carbon requirement to maintain the soil organic carbon level is approximately 0.8 tons of carbon per hectare.

Keywords Rothamsted carbon model $\cdot$ Sahel $\cdot$ Niger $\cdot$ Soil organic matter · Millet

\section{Introduction}

The soil organic matter (SOM) levels in the West African semi-arid tropics are showing severe reduction because of continuous cultivation. Reductions in SOM levels have resulted in decreased soil productivity (Fig. 1). It is well known that SOM plays an important role in crop productivity, especially in the infertile sandy soil in this region (Bationo and Mokwunye 1991; Bationo and Buerkert 2001; Franzluebbers et al. 1994; De Ridder and Van Keulen 1990). Therefore, it is essential to obtain long-term information on the rates of organic matter decomposition and annual carbon requirement. Many studies have reported a pronounced effect of application of various organic matters on crop yields in the Sahel (Schlecht et al. 2004; Bationo et al. 1998; Hayashi et al. 2009). Moreover, various agricultural managements were tested in the JIRCAS/ICRISAT/ INRAN collaborative project entitled "Improvement of fertility of sandy soils in the Sahelian zone through organic 


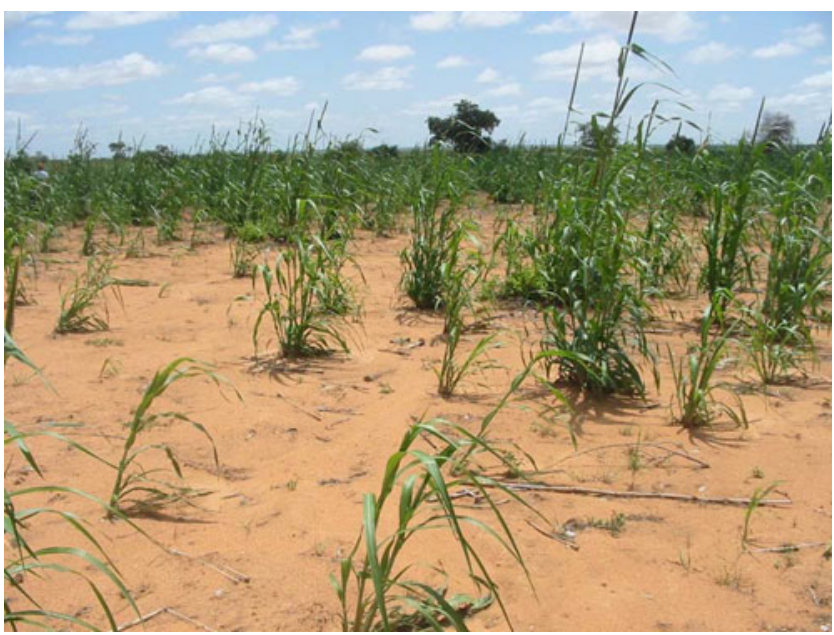

Fig. 1 Pearl millet is one of the major crops that were cultivated under semi-arid climate. The soil distributed in this region is infertile sandy soil

matter management". This project had aimed to propose the technology options that are acceptable and affordable for farmers. Additionally, the project aimed to elucidate the degradation process and kinetics of improving organic matter levels in soil in the Sahel environment, to estimate the nutrient-holding capacity of sandy soils as affected by organic matter application both on a short- and long-term basis, and to identify the synergistic interaction and agronomic significance of combinations of organic and inorganic fertilizers.

However, the effect of organic matter application on the sustainability of crop production has not been properly evaluated, because previous studies have only reported short-term results and not long-term trials. Although a model simulation approach would be effective for evaluating long-term sustainability, most of the existing SOM dynamic models are configured for the temperate zone. Therefore, the Rothamsted carbon model (Roth-C) was validated for use in the Sahelian zone to estimate long-term soil organic carbon (SOC) dynamics (Nakamura et al. 2011). And then, Roth-C was used to evaluate various technical options that have been proposed for semi-arid tropics in Niger. This investigation aimed to elucidate the annual carbon requirement for sustainable soil organic carbon management through Roth$\mathrm{C}$ estimation of suggested technical options in Niger.

\section{Materials and methods}

\subsection{Study sites}

Three experiments were conducted to elucidate the effects of various agronomic technical options on crop yields. Two of these three experiments were conducted in the
International Crop Research Institute for Semi-Arid Tropics, West and Central Africa (ICRISAT-WCA), located in Sádore, $45 \mathrm{~km}$ south of Niamey, the capital of Niger, at an altitude of $240 \mathrm{~m}$ above sea level. The climate of Sádore is characterized by a short rainy season from June to September (Subbarao et al. 2000; Sivakumar 1986), with an annual average precipitation of approximately $560 \mathrm{~mm}$. The other study was conducted in the Fakara region located $50 \mathrm{~km}$ northeast of Niamey. The soil distributed in the Sádore and Fakara regions is a Psammentic Paleustalfs. The three experiments fully discussed about crop production aspects in each citation but did not show the long-term SOC dynamics and the assessment of long-term effect of these agricultural technical options. So, this paper attempted to estimate the long-term SOC dynamics of these three experiments through the model approach.

Experiment 1 focused on the effect of cropping pattern and cropping density of millet (Pennisetum glaucum [L.] R. Br.) and cowpea (Vigna unguiculata [L.] Walp.) intercropping on millet yield. The details of this experiment design were mentioned in Saidou et al. (2010a). They tried to elucidate the effect of cowpea-millet rotation on crop yields and soil fertility using a new cropping design, i.e., 4:4 line cropping against 1:1 line cropping, and with three levels of cowpea planting densities (low, 5,882-6,275 stands ha ${ }^{-1}$; medium, 10,588-11,503 stands $\mathrm{ha}^{-1}$; and high, 29,41232,418 stands $\mathrm{ha}^{-1}$ ). The trials were conducted from 2008 to 2009. Initial SOC conditions, crop yields, and annual carbon input are shown in Table 1. A local millet variety "hiny kirey" and an identified dual-purpose mediummaturing cowpea variety, TN256-87, were used.

Experiment 2 was conducted to elucidate the effect of cowpea intercropping combined with manure and/or chemical fertilizer application on pearl millet yield (Saidou et al. 2010b). The initial condition and annual inputs of this experiment are shown in Table 1. This experiment was conducted from 2007 to 2009, in a randomized complete block design with three replications. As shown in Table 1, the treatments consisted of millet monocropping and intercropping of millet and cowpea. Randomized blocks were subjected to different fertilizer applications: no fertilizer (control), chemical fertilizer diammonium phosphate $(2 \mathrm{~g}$ hill $\left.^{-1}\right)$, transported manure ( $6 \mathrm{t}$ dry matter (DM) ha ${ }^{-1}$ ), and a combination of chemical fertilizer and transported manure. The crops were planted at a low density of $1.4 \times 1.4 \mathrm{~m}$ in mid-June and harvested in October. The same cultivars of millet and cowpeas as those of experiment 1 were selected.

Experiment 3 was conducted from 2008 to 2009, as a generalization of suggested technical options within experiments 1 and 2 (H. Omae, JIRCAS 2010, personal communication). This experiment included the 1:1 and/or 4:4 crop design treatments, selected cowpea varieties, and several different fertilizers such as manure, crop residue, and 





chemicals. The authors attempted to elucidate the farmer's selection from suggested techniques and to summarize the optimal combination of these techniques for farmers. Manure and crop residues were applied at the rate of 9 and $6 \mathrm{t}$ $\mathrm{DM} \mathrm{ha}^{-1}$, respectively. Experiment 3 was conducted in eight sites of six villages in the Fakara region: Tchigo Tegui, Kodey, Yermadey, Bokossay, Katanga, and Maourey Koira Zeno, as replications. The mean initial SOC values and carbon input within eight replications are shown in Table 1.

\subsection{Soil analysis}

Soil samples were air-dried for 1 week, followed by crushing and sieving through a 2-mm sieve. Soil organic carbon content was determined by the Walkley-Black method (Nelson and Sommers 1982). Concentrated $\mathrm{H}_{2} \mathrm{SO}_{4}$ was added to a mixture of soil and aqueous $0.167 \mathrm{~mol} \mathrm{~L}^{-1} \mathrm{~K}_{2} \mathrm{Cr}_{2} \mathrm{O}_{7}$ solution. After 30-min incubation, residual $\mathrm{K}_{2} \mathrm{Cr}_{2} \mathrm{O}_{7}$ was titrated against $0.025 \mathrm{~mol} \mathrm{~L}^{-1} \mathrm{FeSO}_{4}$. Additionally, carbon contents of crop and crop residue were also determined by the Walkley-Black method.

\subsection{Model set-up}

To elucidate SOC dynamics, the Roth-C (version 26.3) (Coleman and Jenkinson 1996) was used. Roth-C is the most frequently used model that has been tested under various climatic and/or agricultural conditions in the world.

The detailed model structure was described by Coleman and Jenkinson (1996). This model simulates SOC dynamics with partitioning of SOC for four active SOC fractions and inert organic matter (IOM). Active SOCs were partitioned as follows: decomposable plant material (DPM), resistant plant material (RPM), microbial biomass, and humified organic matter. In modelling each set of experimental data, we set the initial SOC contents that were measured at the beginning of each experiment and then simulated the changes in SOC with time for each management scenario. These initial SOC contents (in tons of $\mathrm{C}$ per hectare) were calculated from the analysed SOC concentration and bulk densities. For this analysis, soil samples were gathered at a depth of $0-15 \mathrm{~cm}$ in experiments 1 and 2 , and $0-30 \mathrm{~cm}$ in experiment 3 . Simulations were carried out using this depth.

The annual organic matter input used for model calculation was shown in Table 1. The annual organic matter input was calculated as the sum of carbon contents in amended organic fertilizer and in belowground biomass of cultivated crops. All the aboveground biomass was removed once when the crop was harvested. And then, the manure or crop residue application was done. The belowground biomass was estimated as $11 \%$ of the aboveground biomass for millet and as $20 \%$ of aboveground biomass for cowpea, respectively.
For the climatic condition in the research site, monthly mean air temperatures, precipitation, and open pan evaporation were obtained in ICRISAT-WCA. Annual precipitation was set up as $561.6 \mathrm{~mm}$ that was the mean precipitation of the previous decade. Minimum air temperature was $24.8^{\circ} \mathrm{C}$ in January, and maximum air temperature was $34.2^{\circ} \mathrm{C}$ in April, in the model prediction, respectively. The rate-modifying factor for soil moisture in Roth-C was a minimum of 0.2 during the dry season and a maximum value of 1.0 during the rainy season (from July to September) in all cases.

The specified model parameters are the same as Nakamura et al. (2011). Authors calculated the initial allocated amounts of SOC in each of the five compartments according to existing studies (Jenkinson et al. 1999; Shirato and Yokozawa 2005; Coleman and Jenkinson 1996). This estimated C input was divided equally over 12 months according to Coleman and Jenkinson (1996). Soils were assumed to be covered with vegetation throughout the year before the initiation of the experiments. A DPM/RPM ratio of 1.44 , a recommended value for most agricultural crops and grass (Coleman and Jenkinson 1996), was applied. The values of IOM were calculated by the equation outlined by Falloon et al. (1998).

\subsection{Validation of the Rothamsted carbon model}

Nakamura et al. (2011) verified the applicability of the Roth-C model using datasets from two long-term experiments with and without crop residue applications; those were performed by ICRISAT-WCA (experiments 4 and 5). In this long-term experiment, the SOC values in the case without crop residue management decreased with time in approximately ten cultivated years. In contrast, in the case with crop residue application, the predicted SOC remained roughly equal to the initial SOC value during the term observed.

In these two experiments, the long-term actual SOC change was obtained for 27 and 24 years, respectively. One experiment was conducted to examine the relations between crop yields and long-term fertilizer application, including the application of no fertilizer, crop residue, chemical fertilizer, and a crop residue and chemical combination. The other experiment focussed on elucidating the long-term effect of ridging, rotation, and crop residue applications on millet yield. The detailed information of these two experiments have been described in studies by Geiger et al. (1992) and Subbarao et al. (2000), respectively.

Figure 2 indicated the relationship between predicted and observed SOC values of the long-term experiment about long-term effect of pearl millet and cowpea rotations under different managements. The managements include ridging, intercropping, crop residue application, and rotation. The 


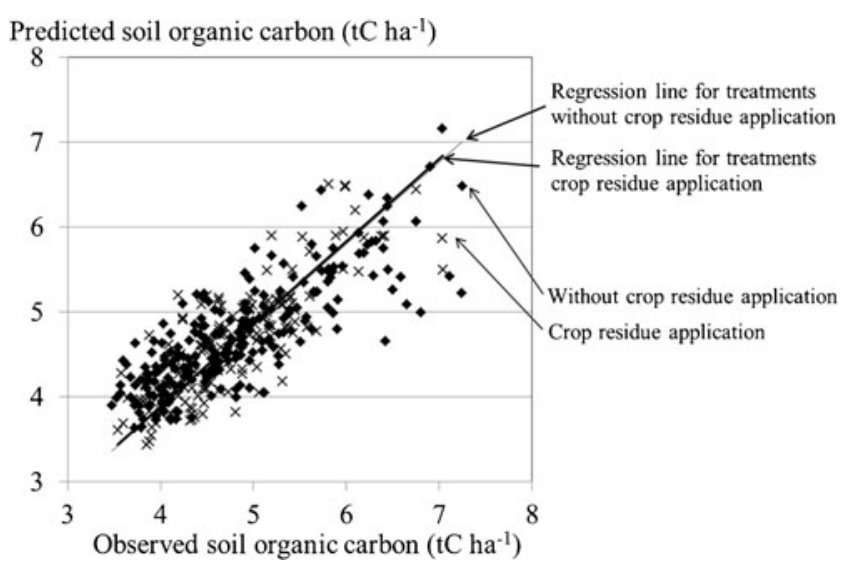

Fig. 2 Relationships between soil organic carbon values predicted by the Rothamsted carbon model and observed in the experiment of longterm effect of pearl millet and cowpea rotation under different managements. The regression equation for crop residue application was $y=$ $0.972 x$ and for treatments without crop residue application was $y=$ $0.967 x$. The determination coefficients were 0.636 and 0.449 , respectively

correlation coefficients between predicted and observed value showed a significantly high value, $0.797(p<0.001)$, in crop residue application and $0.670(p<0.001)$ in non-crop residue, respectively. Mostly, the Roth-C modelled values agreed well with the actual SOC value. RMSE and LOFIT, the statistical indicators of agreement between predicted and observed values, showed a significant conformity between the predicted and observed SOC values in all treatments (Nakamura et al. 2011). This fact means that Roth-C can estimate long-term SOC dynamics of various agricultural treatments in the Sahel and also can estimate those of several technical options that developed with short-term trials.

\section{Results and discussion}

\subsection{Effect of various managements on long-term SOC accumulation}

As shown in Fig. 3, SOC dynamics in experiment 1 indicated a notable decrease of SOC among all treatments. Saidou et al. (2010a) reported that the combination of the four rows millet/four rows cowpea design and crop rotation management provided a significantly high total biomass. Additionally, belowground biomass of millet and cowpea also increased as calculated in Table 1. In this experiment, the aboveground biomass of each crop was not returned to the soil. Therefore, the increase in aboveground biomass of the crop would not affect SOC accumulation directly. Despite the fact that the belowground biomass increased, SOC accumulation was not affected because of the high decomposition rate of organic material in the Sahel. Although this experiment showed an increase in crop yield against traditional management, it was also estimated that non-organic matter application cultivation cannot accumulate SOC in the Sahel.

SOC dynamics estimation in experiment 2 was shown in Fig. 3. The managements that included manure application indicated a pronounced increase of SOC in long-term estimates. It seemed that the amount of organic carbon applied as manure was enough to maintain or increase SOC, even in the highly decomposing condition of the Sahel. In contrast, SOCs in the chemical fertilizer application and control showed a remarkable decline, as well as the results of the estimations in experiment 1. While Saidou et al. (2010b) noted an increase in total biomass yield in millet/cowpea intercropping compared to monocropping due to the input of cowpea biomass, SOC dynamics estimation did not show a significant difference between monocropping and intercropping (Fig. 3).

Experiment 3 was a complex trial performed under the intercropping management, consisting of several technical options, including selected cowpea variety, fertilizer application, and cropping design. All options were evaluated under the millet/cowpea intercropping system. The predicted SOC in experiment 3 revealed that organic matter application, and not cropping design and/or cowpea variety, was effective on increasing organic matter. Manure application $\left(3.6 \mathrm{tC} \mathrm{ha}^{-1}\right)$ showed a pronounced increase of SOC (Fig. 4). Moreover, crop residue application also indicated SOC accumulation (Fig. 4). The chemical fertilizer application and control declined in long-term SOC dynamics. This fact indicates that these organic matter application rates were sufficient for residual accumulation of organic matters in the Sahel. However, such application rates might be recognized as impractical for farmers due to socioeconomical constraints. Therefore, the properly targeted value for the organic matter application rate needs to be calculated. Additionally, it was notable that all of the suggested technical options without organic matter application also increased crop yield compared with traditional management in the short-term trials, while showing a pronounced decline in SOM dynamics.

3.2 Annual carbon requirement estimation for sustainable soil organic matter management in the Sahel

The annual carbon requirement for maintaining SOC contents in the study area was calculated from simple linear regression analysis between actual annual carbon input and predicted SOC changes after a 10 -year cultivation period based on 59 treatments: 27 from technical options tested in experiments 1,2 , and 3 , by the JIRCAS project regarding soil fertility improvement in Niger, and 32 treatments conducted in two long-term experiment fields that were used for 


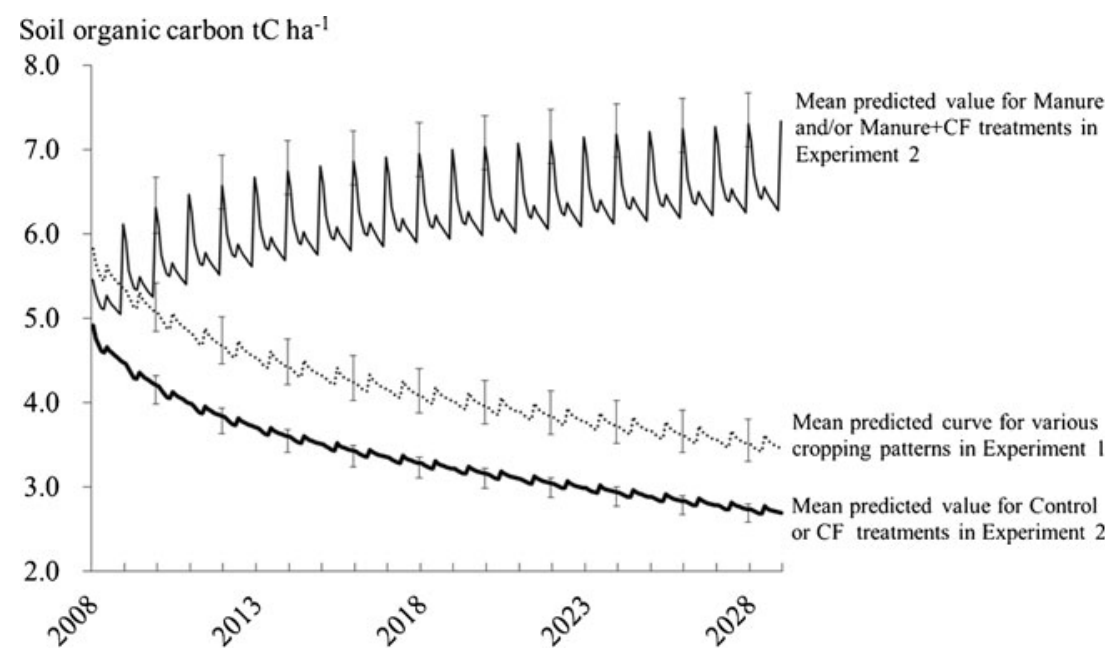

Fig. 3 Long-term estimations of soil organic carbon dynamics in experiment 1 and 2. Experiment 1 includes six treatments of cropping pattern and cropping density of millet and cowpea for intercropping without organic matter application. Prediction curves for experiment 2 were drawn as mean prediction of treatments with manure application

model validation in Nakamura et al. (2011). The initial SOC, mean value of annual inputted carbon, and predicted carbon changes in 10 years are presented in Table 2.

The authors focussed on SOC changes in 10-year cultivation to elucidate the annual carbon requirement because most of the SOC was reduced in this period, as shown in Figs. 2 and 3. Moreover, Nakamura et al. (2011) indicated that the model prediction was possible to show the underestimation after 10 years in some cases, while the estimation fit well to observed SOC changes within 10 years.

The computed annual carbon requirement was about $0.8 \mathrm{t}$ $\mathrm{C} \mathrm{ha}^{-1}$ in this region (Fig. 5). Annual input of $0.8 \mathrm{tC} \mathrm{ha}^{-1}$ can be converted to approximately $1.6-2.0 \mathrm{t} \mathrm{ha}^{-1}$ as crop residues and 2.0-4.0 $\mathrm{t} \mathrm{ha}^{-1}$ as transferred manure. The manure applications indicated a higher accumulation rate compared with crop residue application. The rate of crop residue application was often dependent on the biomass or without organic matter application combined with chemical fertilizer $(\mathrm{CF})$, respectively. Treatments without organic matter application showed definite soil organic carbon declines. The bars indicate the maximum and minimum of predicted values

yield in the field, whereas the manure application rate was not limited by yield. Even when the crop residue was applied, there were several cases where the applied carbon was less than the required amount. This appeared to be due to the low yield of plant biomass.

The annual carbon requirement for sustainable cultivation in West Africa has been well discussed in Bationo et al. (2007). On the aspects of SOC accumulation, the $K$ value, calculated as the percentage of organic carbon loss per year, was introduced. The $K$ value for agro-ecosystem in West Africa was $4.7 \%$ in sandy soil, whereas it was $2 \%$ for sandy loam (Pieri 1989; Bationo and Buerkert 2001). And this $K$ value is known to vary according to agricultural treatments such as mulching, cropping system, and tillage (Roose and Barthes 2001; Bationo and Buerkert 2001). This $K$ value can be calculated as $0.1-0.24 \mathrm{tC} \mathrm{ha}^{-1}$ year $^{-1}$ in our research site where approximately $5 \mathrm{tC} \mathrm{ha}^{-1}$ of SOC was
Fig. 4 Long-term estimations of soil organic carbon dynamics in experiment 3 ; the prediction curves were drawn as mean prediction of manure, crop residue, and without organic matter applications, respectively. Treatments without organic matter application showed soil organic carbon declines. The bars indicate the maximum and minimum of predicted values within three groups

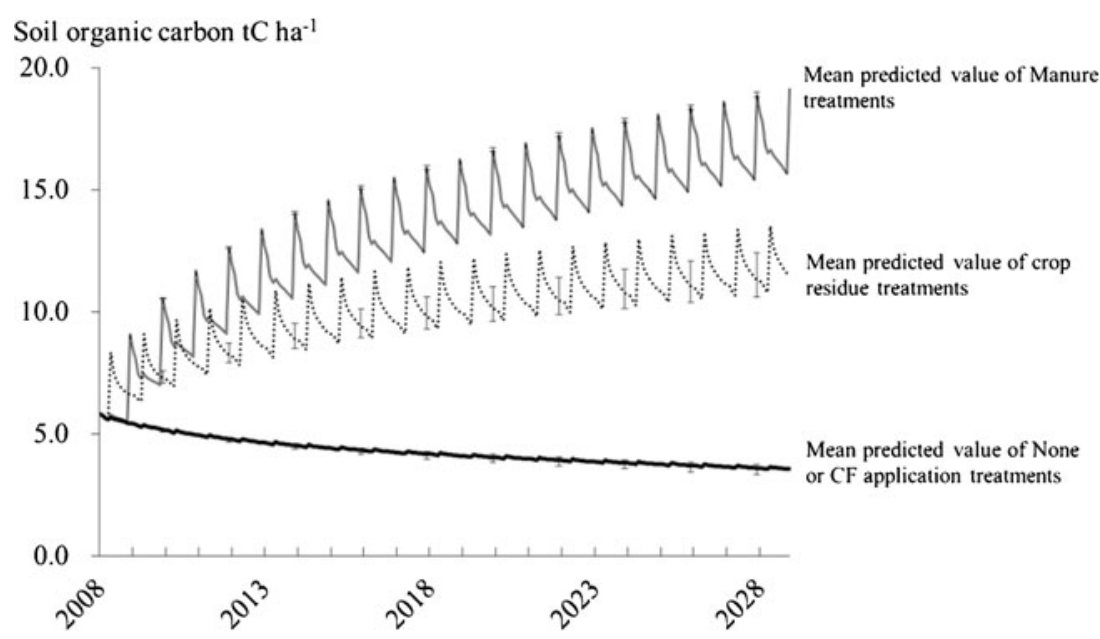


Table 2 Initial soil organic carbon, annual carbon input, and predicted carbon balance during 10 years in two long-term experiments conducted in ICRISAT-WCA

\begin{tabular}{|c|c|c|c|c|c|c|c|}
\hline \multirow[t]{2}{*}{ Treatment } & \multirow[t]{2}{*}{ Crop } & \multicolumn{3}{|c|}{ Without crop residue application $\left(\mathrm{tC} \mathrm{ha}^{-1}\right)$} & \multicolumn{3}{|c|}{ Crop residue application $\left(\mathrm{tC} \mathrm{ha}^{-1}\right)$} \\
\hline & & Initial SOC & $\begin{array}{l}\text { Annual carbon } \\
\text { input }\end{array}$ & $\begin{array}{l}\text { Predicted carbon } \\
\text { balance in } \\
10 \text { years }\end{array}$ & Initial SOC & $\begin{array}{l}\text { Annual carbon } \\
\text { input }\end{array}$ & $\begin{array}{l}\text { Predicted carbon } \\
\text { balance in } \\
10 \text { years }\end{array}$ \\
\hline
\end{tabular}

Experiment 4: combination effect of crop residue and chemical fertilizer (from 1983)

$\begin{array}{lllllllr}\text { Control } & \text { Millet/cowpea } & 3.44 & 0.07 & -1.17 & 3.81 & 0.51 & -0.28 \\ \text { Chemical fertilizer } & \text { Millet/cowpea } & 3.84 & 0.17 & -1.12 & 4.05 & 1.17 & 1.12\end{array}$

Experimet 5: long-term experiment of millet/cowpea intercropping, rotation, ridge management (from 1986, crop residue was applied from 1989)

\begin{tabular}{|c|c|c|c|c|c|c|c|}
\hline $\begin{array}{l}\text { Traditional practice with } \\
\text { improved variety }\end{array}$ & Millet & 5.69 & 0.03 & -2.07 & 3.94 & 0.37 & -0.70 \\
\hline Intercropping/ridge/no rotation & Millet/cowpea & 6.32 & 0.10 & -1.66 & 4.55 & 1.03 & 0.64 \\
\hline Intercropping/ridge/rotation $1^{\text {a }}$ & Millet/cowpea & 5.96 & 0.17 & -1.91 & 4.99 & 0.87 & 0.03 \\
\hline Intercropping/ridge/rotation $2^{\mathrm{b}}$ & Millet/cowpea & 6.14 & 0.13 & -2.05 & 4.96 & 0.66 & -0.38 \\
\hline Intercropping/flat/no rotation & Millet/cowpea & 5.33 & 0.07 & -1.86 & 4.06 & 0.96 & 0.68 \\
\hline Intercropping/flat/rotation 1 & Millet/cowpea & 5.65 & 0.13 & -1.87 & 4.07 & 0.77 & 0.22 \\
\hline Intercropping/flat/rotation 2 & Millet/cowpea & 5.38 & 0.10 & -1.83 & 4.20 & 0.60 & -0.24 \\
\hline Sole/ridge/no rotation & Millet & 5.65 & 0.10 & -1.93 & 4.47 & 0.97 & 0.56 \\
\hline Sole/ridge/rotation 1 & Millet/cowpea & 6.28 & 0.17 & -2.01 & 5.61 & 1.02 & 0.18 \\
\hline Sole/ridge/rotation 2 & Millet/cowpea & 5.83 & 0.14 & -1.92 & 5.11 & 0.93 & 0.30 \\
\hline Sole/flat/no rotation & Millet & 5.47 & 0.09 & -1.88 & 3.54 & 0.90 & 0.72 \\
\hline Sole/flat/rotation 1 & Millet/cowpea & 6.23 & 0.17 & -2.00 & 4.84 & 0.87 & 0.16 \\
\hline Sole/flat/rotation 2 & Millet/cowpea & 5.38 & 0.10 & -1.82 & 3.85 & 0.73 & 0.20 \\
\hline $\begin{array}{l}\text { Traditional practice with } \\
\text { local variety }\end{array}$ & Millet & 7.03 & 0.07 & -2.50 & 6.10 & 1.14 & 0.33 \\
\hline
\end{tabular}

SOC soil organic carbon

${ }^{\mathrm{a}}$ Rotation 1: millet cultivation in even years

${ }^{\mathrm{b}}$ Rotation 2: millet cultivation in odd years

shown initially. It seems that it is an apparently low value compared with the predicted annual carbon requirement.

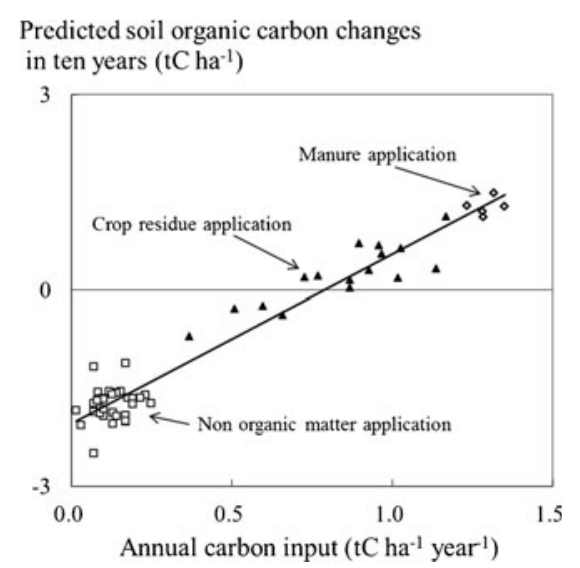

Fig. 5 Relationship between annual carbon input and predicted soil organic carbon changes in a 10-year period in the Sahel. The regression equation was $y=2.584 x-2.039$, and the determination coefficient was $0.948(p<0.001)$. The annual carbon requirement to maintain the soil organic carbon contents in the Sahel was computed as $0.8 \mathrm{tC} \mathrm{ha}^{-1}$ from this equation
However, as Roose and Barthes (2001) showed, the carbon losses of cropped land are highly affected by erosion in West Africa. Our regression analysis calculates the annual carbon requirement from total carbon input as organic amendments and residual plant biomass, but does not include carbon loss by various types of erosion. And so, the predicted value of the annual carbon requirement has to be considered as the targeted application rate of organic materials assuming the organic carbon would be partly lost by erosion.

And amounts of organic carbon in the soil tend, over time, to reach an equilibrium value, the size of which depends on local environmental conditions (e.g. soil texture, rainfall) and land utilisation and management practices (e.g. cropping systems, residue management, inputs both organic and inorganic). Soil under long-term, continuous cultivation tends towards a low equilibrium $\mathrm{C}$ value, though this may be mitigated by inputs, especially organic inputs. So, the effectiveness of adding $0.8 \mathrm{tC} \mathrm{ha}^{-1}$ annum $^{-1}$ will depend on whether the soil is already degraded and to what degree. On a degraded soil, $0.8 \mathrm{tC} \mathrm{ha}^{-1}$ annum $^{-1}$ will maintain the soil $\mathrm{C}$ content and crop yields, though at very low levels. But of 
course, in the undegraded soil, the higher input may be required. So, this predicted value needs to be defined as the carbon requirement for maintaining SOC at equilibrium of SSA.

\section{Conclusion}

The annual carbon requirement to maintain the soil organic carbon level for sustainable agriculture in the Sahel was estimated to be approximately $0.8 \mathrm{tC} \mathrm{ha}^{-1}$ through Roth-C prediction using several experiments that were conducted in Niger. The suggested technical options were effective for improving crop production even though organic matter has not been applied; however, SOC level declines without application of organic matter. It seems that the soil productivity will decline with soil organic carbon decrease in these technical options. To maintain the soil productivity sustainably, organic matter should be applied under conscious control to target the estimated carbon requirement. This estimated carbon requirement value, however, does not ensure good crop yields.

Acknowledgments The authors greatly appreciate the entire staff of ICRISAT-WCA for their technical support. And also, we appreciate all TSBF staff for providing us the valuable long-term dataset. This investigation was conducted under the JIRCAS-ICRISAT collaborative project named "Improvement of Fertility of Sandy Soils in the SemiArid Zones of West Africa Through Organic Matter Management". The authors appreciate the reviewers and the editorial board for giving sincere discussions and suggestions.

\section{References}

Bationo A, Buerkert A (2001) Soil organic carbon management for sustainable land use in Sudano-Sahelian West Africa. Nutr Cycl Agroecosyst 61:131-142. doi:10.1023/A:1013355822946

Bationo A, Mokwunye AU (1991) Role of manures and crop residue in alleviating soil fertility constraints to crop production: with special reference to the Sahelian and Sudanian zones of West Africa. Fertil Res 29:117-125. doi:10.1007/978-94-011-3224-4_19

Bationo A, Lompo F, Koala S (1998) Research on nutrient flows and balances in West Africa: state-of-the-art. Agric Ecosyst Environ 71:19-35. doi:10.1016/S0167-8809(98)00129-7

Bationo A, Kihara J, Vanlauwe B, Waswa B, Kimatu J (2007) Soil organic carbon dynamics, functions and management in West African agroecosystems. Agric Syst 94:13-25. doi:10.1016/j.agsy.2005.08.011

Coleman K, Jenkinson DS (1996) RothC-26.3 - a model for the turnover of carbon in soil. In: Powlson DS, Smith P, Smith JU (eds) Evaluation of soil organic matter models using existing long-term datasets. NATO ASI series I, 38th edn. Springer, Berlin, pp 237-246

De Ridder N, Van Keulen H (1990) Some aspects of the role of organic matter in sustainable intensified arable farming systems in the
West-African semi-arid-tropics (SAT). Fertil Res 26:299-310. doi:10.1007/BF01048768

Falloon P, Smith P, Coleman K, Marshall S (1998) Estimating the size of the inert organic matter pool from total soil organic carbon content for use in the Rothamsted carbon model. Soil Biol Biochem 30:1207-1211. doi:10.1016/S0038-0717(97)00256-3

Franzluebbers K, Juo ASR, Manu A (1994) Decomposition of cowpea and millet amendments to a sandy Alfisol in Niger. Plant Soil 167:255-265. doi:10.1007/BF00007952

Geiger SC, Manu A, Bationo A (1992) Changes in a sandy sahelian soil following crop residue and fertilizer additions. Soil Sci Soc Am J 56:172-177. doi:10.2136/sssaj1992.03615995005600010027x

Hayashi K, Abdoulaye T, Matsunaga R, Tobita S (2009) Appraisal of local farmer's practices on land management for a guideline of agricultural development in the Sahel Zone of Niger, West Africa. JARQ 43:63-69

Jenkinson DS, Meredith J, Kinyamario JI, Warren GP, Wong MTF, Harkness DD, Coleman K (1999) Estimating net primary production from measurements made on soil organic matter. Ecol 80:2762-2773. doi:10.1890/0012-9658(1999)080[2762: ENPPFM]2.0.CO;2

Nakamura S, Hayashi K, Omae H, Ramadjita T, Dougbedji F, Shinjo H, Saidou AK, Tobita S (2011) Validation of soil organic carbon dynamics model in the semi-arid tropics in Niger, West Africa. Nutr Cycl Agroecosyst 89:375-385. doi:10.1007/s10705-0109402-4

Nelson LE, Sommers DW (1982) Total carbon, organic carbon, and organic matter. In: Page AL, Miller RH, Keeney DR (eds) Methods of soil analysis - part 2: chemical and microbiological properties. Agronomy series no. 9. American Society of Agronomy, Inc, Madison, pp 539-580

Pieri C (1989) Fertilité des terres de savane. Bilan de trente ans de recherche et de développement agricoles au Sud du Sahara. Ministère de la Coopération. CIRAD, Paris

Roose E, Barthès B (2001) Organic matter management for soil conservation and productivity restoration in Africa: a contribution from Francophone research. Nutr Cycl Agroecosyst 61:159-170. doi:10.1023/A:1013349731671

Saidou AK, Omae H, Tobita S (2010a) Combination effect of crop design and crop densities in the system of millet/cowpea rotation in the Sahel, West Africa. Am-Eurasian J Agric Environ Sci 7 (6):644-647

Saidou AK, Omae H, Tobita S (2010b) Combination effect of intercropping, application of chemical fertilizer and transported manure on millet/cowpea growth and nitrogen, phosphorus balances in the Sahel. Am Eurasian J Agron 3(2):30-35

Schlecht E, Hiernaux P, Achard F, Turner MD (2004) Livestock related nutrient budgets within village territories in western Niger. Nutr Cycl Agroecosyst 68:199-211. doi:10.1023/B: FRES.0000019453.19364.70

Shirato Y, Yokozawa M (2005) Applying the Rothamsted carbon model for long-term experiments on Japanese paddy soils and modifying it by simple tuning of the decomposition rate. Soil Sci Plant Nutr 51:405-415. doi:10.1111/j.1747-0765.2005.tb00046.x

Sivakumar MVK (1986) Climate of Niamey. Progress Report No.1 Niger: ICRISAT Sahelian Center.

Subbarao GV, Renard C, Payne WA, Bationo A (2000) Long-term effects of tillage, phosphorous fertilization and crop rotation on pearl millet-cowpea productivity in the West-African Sahel. Exp Agric 36:243-264. doi:10.1017/S0014479700002106 